\title{
CRITERIA, LANGUAGE AND THE REVITALISATION OF BLACK THEOLOGY
}

\author{
G Brand \\ Systematic Theology and Ecclesiology \\ Stellenbosch University
}

\begin{abstract}
Drawing on debates within Black Theology, it is possible to identify, inductively, a set of criteria for judging theological constructs, that can be defended both within the tradition of Black Theology and with reference to theology in general. This meta-theological model, when considered against the background of the present South African context - in both its continuity and its discontinuity with the past - reveals not only the continuing relevance of Black Theology, but also some new themes that must be explored using the resources of Black Theology. Among these is language as a 'question of power' (Chomsky) - specifically the move from racial to linguistic capitalism as an aspect of the black experience, which has implications, not only for the content, but also for the conduct, of Black Theology during its 'revitalisation phase'.
\end{abstract}

Key Words: Black Theology, African Theology, Criteria, Language, Meta-theology, Capitalism

\section{Revitalising Black Theology}

Calls for the revitalisation or 'rehabilitation' of Black Theology ${ }^{1}$ presuppose that all is not well with this theological approach - a view occasionally expressed by South African theologians. Mokgethi Mothlabi, for example, writes: "South African theology ... seems to have lost its bearing and sense of direction, especially since the political change that took place in the country in 1994. Black theologians, in particular, have seemingly gone into recess ... they have been mesmerised by the new developments that have taken place in the country since their political liberation and have not yet found a new way to relate to them."2

Motlhabi's use of the phrase 'not yet' (emphasis added) indicates, however, that he is not of the view that Black Theology should be left behind or displaced by other approaches. On the contrary, he wants to show "that African and Black Theology ${ }^{3}$ still have a role to play in theological reflection in South Africa". And indeed, talk of revitalisation and rehabilitation signals not only a negative critique of Black Theology, but also a positive expectation that it may yet prove relevant in new contexts. Only that which holds promise, despite its apparent lack of vitality or its seeming waywardness, is worth revitalising or

\footnotetext{
See e.g. Mokgethi Motlhabi, African Theology / Black Theology in South Africa: Looking Back, Moving On, Pretoria, 2008, $\mathrm{x}$.

Motlhabi advocates the "merging" of these two theological approaches, see ibid, x-xi. See also my Speaking of a Fabulous Ghost: In Search of Theological Criteria, with Special Reference to the Debate on Salvation in African Christian Theology, Frankfurt, 2002, in which I use the term "African Christian Theology" to refer to both approaches.

4 Mothabi, African Theology, x.
}

2 Ibid. 
rehabilitating. Calling for change and renewal can, thus, be seen as an expression of commitment to, rather than disloyalty towards, the tradition of Black Theology.

What changes are needed in order to bring about the renewal of Black Theology? In pointing to the political transition in South Africa as a major reason for Black theologians' apparent 'recess', Motlhabi provides a useful starting point for answering this question. One of the enduring contributions of Black Theology and other 'contextual' theologies has been the insight, not that theology should be, but that it always already is, rooted in a specific historical and social context. The 'ought' that follows from this 'is', according to contextual theologians, is simply that theologians ought to be conscious, and give explicit account, of how contexts shape their theological thinking. ${ }^{5}$ It is, therefore, understandable that a change in the context in which Black Theology is to be practised, will call for changes in that theology itself. It would be a betrayal of the central thrust of Black Theology if this were denied. At the same time, the changes called for by the changed context need not necessarily entail moving away from the basic meta-theological assumptions that have undergirded Black Theology thus far. Precisely because the criteria applied by practitioners of Black Theology have always been deliberately employed in a contextrelative way, those criteria could well prove sufficiently flexible, and therefore relevant, with respect to present concerns. ${ }^{6}$

\section{Criteria in Black Theology}

I have tried, elsewhere, ${ }^{7}$ to show that the criteria to which Black/African theologians implicitly appeal in arguing for or against theological positions include demands such as that theology, in an African context, should 'be expressed in African terms', 'reconcile Christianity with the African worldview', 'address African problems', 'be rooted in the African church', 'reconcile Christian commitment with liberation praxis', 'be 'situational', 'be liberating', 'be accountable to the church of the poor", 'remain in conversation with the Christian tradition', 'remain faithful to the revelation in Christ', and 'submit to the authority of Scripture and church tradition'. ${ }^{8}$ This list of criteria was not arrived at deductively - submitting Black/African theology to arbitrary a priori demands - but rather inductively, i.e. by identifying the criteria that are in fact appealed to by African/Black theologians. ${ }^{9}$

$5 \quad$ See my 'African and Western Theologies between Church, University and Society: A Philosophical Inquiry into the Contextuality of Theological Criteria', in: ME Brinkman et al, Theology between Church, University and Society, Leiden, 2001.

6 Vincent Brümmer, 'Dawkins' Religion', Neue Zeitschrift fur Systematische Theologie und Religionsphilosophie 52 (2010), 185, argues that a successful tradition is one that is able to draw creatively on its characteristic "fund of models and metaphors, stories and images, memories and assumptions, institutions and practices etc. from which [it] can derive and adapt what is needed to make sense of the context within which we live".

7 Brand, Speaking, 195-209.

8 As far as the last criterion mentioned is concerned, I pointed out that discussions in Black and African theologies "yielded the ... insight that, since all of the criteria to be applied in theology are culture and context relative, ... a theological reading of Scripture must by its very nature also be influenced deeply by the cultural environment and socio-political context within which it is undertaken" (Ibid, 217), and that "our interpretation of the tradition is partly determined by extra-biblical (contextual) criteria" (209).

9 See Ibid, 27, 36-37. On the advantages of an inductive approach to the study of theological criteria, see also Marcel Sarot, 'Criteria for Doctrinal Development: A Case Study of the Doctrine of God's (Im)passibility', Studia Theologica 50 (1996), 62. 
In a further step ${ }^{10} \mathrm{I}$ then compared this list to the criteria highlighted in the writings of Western theologians - such as consistency and coherence, intelligibility, credibility, relevance, adequacy, Christian identity and authenticity, integrity and accountability. ${ }^{11}$ I concluded that "the criteria invoked by African and Western theologians respectively seem to be roughly similar", that it is "certainly not the case that African theologians place a onesided emphasis on social utility at the expense of other criteria", and that "all the criteria invoked by Western theologians ... have their counterparts in the African discussion". ${ }^{2}$

The most striking difference that emerged, however, is "a far greater stress [on the part of African/Black theologians] on the contextual nature of theological criteria": "In place of a generalised 'reason', African theologians posit a rationality that is culturally determined and context specific ... In place of 'the demands of life', they insist on addressing particular historical circumstances ... Instead of abstractions like 'the Christian community' and 'the Christian form of life', they hold themselves accountable to concrete communities ... In this sense, the whole project of African Christian theology can be regarded as a critique of the abstract and universalist ('imperialist' ...) character of much Western theology." ${ }^{13}$ This critique emerging from Black and African Theology remains important to all types of theology, in whatever context. It is precisely by remaining true to this critical understanding, by taking it seriously, that Black Theology can be revitalised and rehabilitated.

Linked to this critical meta-theology is another feature of Black Theology as it has historically been practised: its critical take on society generally. In this area Motlhabi highlights a crucial aspect in which post-1994 Black Theology has, in his view, lost some of its bearing and is in need of rehabilitation. He calls for a renewed interest in the kind of "critical theological reflection which was once responsible for challenging the evil order of apartheid, thus contributing to the struggle for socio-political change in the country":

The demise of apartheid gave rise in some circles to the slogan 'critical solidarity with the state' ... Unfortunately, this well-intentioned need for critical solidarity has tended to place more emphasis on solidarity while mostly neglecting its critical aspect. The result is that Black Theology has lost its responsiveness to and input into the new socioeconomic problems ..., which still need the critical and prophetic participation of black theologians ... African and black theologians can better help the state by giving praise where it is due, while equally pointing out some of its shortcomings whenever it is necessary to do so. ... If needs be ... respectful public outcry should not be entirely ruled out. ${ }^{14}$

The danger that Motlhabi points to here is one that Allan Boesak already highlighted during the heady days of the struggle against apartheid, when he warned that black theologians who identify too uncritically with the demands of that struggle would be 'wide open for an ideological takeover'. ${ }^{15}$ An abstract debate about whether 'critical solidarity'16 or 'public outcry' is the appropriate strategy for Black Theology in present day South Africa is

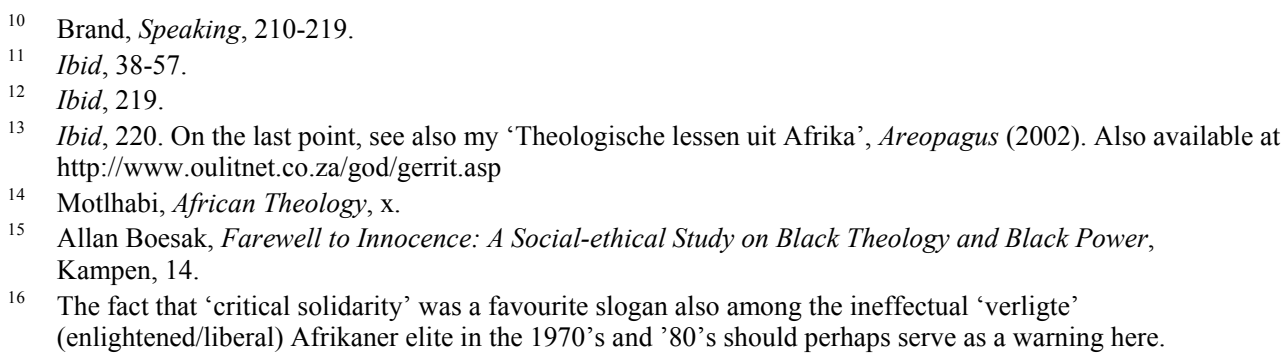

16 The fact that 'critical solidarity' was a favourite slogan also among the ineffectual 'verligte' (enlightened/liberal) Afrikaner elite in the 1970's and '80's should perhaps serve as a warning here. 
probably fruitless. The real challenge is to use the criteria that have already been developed within Black Theology to analyse the context and react appropriately.

\section{The Changed Context}

Probably the most important contextual change that has occurred since 1994 is, as Motlhabi points out, the demise of apartheid. White minority rule has been replaced by majority rule in a democratic dispensation, and one result of this, given the demographics of South Africa, is that the black majority, whose experience was the starting point for Black Theology in the past, has now gained political power. It would be a misunderstanding of the nature of democracy if this change were taken to imply that black theologians should in principle henceforth see itself as an ally of the state, or more specifically, the ruling party. Loyalty to democracy among those who fought for its realisation does not imply supporting whatever government is democratically elected. On the contrary, citizens demonstrate their loyalty to, and belief in, democracy precisely by holding the government of the day accountable. At the same time, it would be a mistake to conclude that citizens, and theologians in particular, should be opposed to the government of the day in principle. The 'correct' critical attitude to adopt should be decided on a case by case basis.

Motlhabi also points to some new global issues that have come to the fore during the last two decades, and to which African/Black Theology should respond, "since they address issues of poverty, oppression and exploitation and the struggle against them", so that "their very concerns coincide with the concerns of these theologies". ${ }^{17}$ Here he specifically discusses "Marxism, Morality and Ideology"18 and "The Spectre of Third World Debt".

Other black theologians, like Tinyiko Maluleke, ${ }^{20}$ have also pointed to such new challenges facing Black Theology, like the ecological crisis, the social impact of communicable disease and gender issues like violence against women and the crisis of male identity. ${ }^{21}$

One social issue that has not received the attention it deserves in Black Theology, and which, if addressed critically, can contribute significantly to the revitalisation of Black Theology (as I shall argue in what follows) is that of language - more specifically, the position of African languages in present day South Africa. ${ }^{22}$

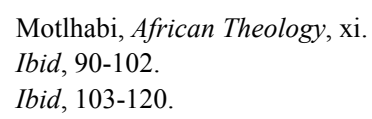

See e.g. his recent (as yet unpublished) paper on the future of Black Theology at the international conference on 'Calvin's Relevance for Today' held at Stellenbosch University from August $3^{\text {rd }}$ to September $2^{\text {nd }}, 2009$.

21 On the latter, see also his 'Taking back the Streets', The Weekender (08/08/2009), 8, and his blog post 'Dying to Be Men' at http://tsmaluleke.blogspot.com (where a longer version of the aforementioned Weekender article can also be accessed under the title 'Imagine a Country ... where Women can Walk').

22 In my 'Spirit, Identity and Culture: The Language of God' (forthcoming) I argue that the Accra Declaration of the World Alliance of Reformed Churches (available at http://www.wcc-coe.org/wcc/what/jpc/accra-e.html), in which the challenge to the churches of "neoliberal economic globalisation" is dealt with, mentions "cultural ... power" in the context of "a system of domination", but does not go on to address this aspect of globalisation in sufficient detail. An important step towards an African theological consideration of the language question was the June 2002 edition of the Journal of African Christian Thought (5:1), dedicated to the theme The Challenge of Mother Tongue for African Thought. However, none of the contributors really dealt with language as a political or justice issue. 


\section{From Racial to Linguistic Capitalism}

A thorough analysis of developments since 1994, against the background of 300 years of colonialism, segregation and apartheid, suggests that language is one of the pivotal factors that will determine the direction in which South African society will develop. To see this, one simply needs to compare the percentage of South Africans who are functionally proficient in English - just over half of the total population ${ }^{23}$ - with the percentages in sectors like the government, the civil service, higher education institutions, and the private sector. While these and other high-status sectors have become much more representative of the total population in racial terms since 1994, it is quite evident that South Africans who are proficient in English, regardless of race, are dramatically over-represented in each of them.

The significance of this discrepancy begins to emerge only when we consider that South Africans' relation to the English language corresponds strongly with various other markers of relative social status and power bequeathed by our history, such as class, gender, urban versus rural origin, and - yes - race. A Pansalb survey ${ }^{24}$ has shown quite clearly that the more light-skinned, wealthy and urban South Africans are, the more likely they are to be proficient in English. Take for instance the finding that, whereas about $60 \%$ of all South Africans regard themselves as proficient in English, this figure drops to only $22 \%$ in the case of speakers of African languages, i.e. of more than $70 \%$ of the population. A language barrier with English as the main criterion of access thus leads automatically to the exclusion of those South Africans who have historically been the most marginalised.

The history of South Africa until 1994 was characterised by the struggle between Afrikaans (formerly Dutch) and English-speaking white South Africans for control over cheap and exploitable black labour. Closely tied to this struggle were the efforts of both groups to establish the dominance of their language across racial boundaries. All over the world, political and economic dominance has always been accompanied by linguistic dominance. With political power firmly in the hands of white Afrikaners, especially after 1948, and economic power mainly in the hands of English-speaking whites, a delicate truce was maintained for 50 years in the form of a bilingual policy, which meant that, unlike whites, black South Africans had to be proficient in two languages in addition to their mother tongues in order to gain access to the limited opportunities for advancement open to them. By contrast, white South Africans enjoyed the benefits of mother-tongue education and access to advancement opportunities through their mother tongues.

Since 1994, Afrikaans has yielded much ground to English as a language of public discourse, or lingua franca of the elite. This has enabled a small minority of black South Africans to advance. It has maintained the privileged position of white English speakers, and has had little impact on the favourable position of white Afrikaans speakers, most of whom are highly proficient in English. However, it has impacted negatively on the majority of Afrikaans speakers, who are black, and has made no difference to the majority of black South Africans, who are as much excluded by English as by Afrikaans, and already face many other obstacles to advancement. African languages have made few inroads into highstatus functions, and have even been marginalised further in many areas.

One of the most important contributions to the understanding of South African reality was the debate sparked by the Black Consciousness Movement in the 1960s and '70s about

23 Pan South African Language Board (Pansalb), Language Use and Language Interaction in South Africa: A National Sociolinguistic Survey, Pretoria, 2000.

24 See previous note. 
whether race or class offered the most suitable perspective from which to analyse the dynamics of injustice in South African society. A consensus gradually emerged in which it was recognised that neither of the two offered a satisfactory explanation without taking cognisance of the other. The term 'racial capitalism' came to serve as shorthand for this insight. $^{25}$

Activist intellectuals came to see that race had functioned throughout our history as a criterion for demarcating the interests of the capitalist class from the oppressed classes. White workers - mainly Afrikaners - were co-opted into the capitalist system by being granted certain privileges in the form of job reservation and, importantly, access to advancement opportunities, especially in the civil service, through their mother tongue, Afrikaans. Thus the white Afrikaner electorate had a stake in maintaining and furthering the interests of the white English-speaking capitalist class, and vice versa. At the same time, racist legislation and a vast apparatus of repression, negotiated between the state and the private sector, ensured that blacks remained economically dependent, a source of cheap and exploittable labour with which to enrich whites. Thus an unlikely alliance was forged between an Afrikaner nationalist politics of recognition and empowerment of poor whites on the one hand, and the interests of the white, English-speaking corporate sector on the other. ${ }^{26}$

This analysis has to be updated if it is to serve our understanding of the transition over the last two decades. The accumulation strategy of apartheid finally collapsed in 1994 under various local and international pressures of an economic and political nature. A severe shortage of skilled labour and increasing political unrest and instability led to an economic crisis that rendered the racial criteria of privilege impossible to maintain, and required the accelerated establishment of a black middle class with a stake in the capitalist system. ${ }^{27}$ This proto-middle class was already available in the ranks of the ANC, which had, quite understandably, been lead by a Western educated black elite since its inception just as, earlier, Afrikaner nationalism drew its leadership from among a small number of Afrikaner notables.

Unlike the Afrikaner nationalist leaders, however, the leadership of the ANC were for the most part educated in schools and universities in South Africa or overseas where English was the language of instruction and 'British civilisation' the focus of aspiration. They belonged to what African historians sometimes call the 'missionary elite' - those few Africans who were targeted for education and relative privilege by churches and other agents of British colonialism in a society dominated by white English speakers. ${ }^{28}$

25 See 'The Black Consciousness Movement' at http://www.sahistory.org.za/pages/governence-projects/blackconsciousness/biko/timeline.htm: On 11 and 12 June, 1983, "the National Forum, representing 170 black organisations, holds its first Conference at Hammanskraal near Pretoria. Delegates from political, religious, student and trade union movements unanimously adopt a manifesto identifying racial capitalism as the real enemy and pledging to establish a Socialist republic." (Emphasis added.) For a historical survey of the debate, see Neville Alexander, in An Ordinary Country: Issues in the Transition from Apartheid to Democracy in South Africa, Berghahn Books, 2003 ( $1^{\text {st }}$ edition: University of Natal Press, 2002), 9-28.

26 This "accumulation strategy" is well described in Sampie Terreblanche's book A History of Inequality in South Africa 1652-2002, Durban 2002.

27 Apart from the book by Terreblanche mentioned in the previous note, two of the most insightful explanations of the demise of apartheid are provides by Alexander in An Ordinary Country, and P Eric Louw in The Rise, Fall and Legacy of Apartheid, Praeger Publishers, 2004.

28 On the "missionary elite", see e.g. Sarah Elizabeth Johnson, "Free Methodist Mission in South Africa, 1891-1960: Social Conformity or Prophetic Challenge?", Wesleyan Theological Journal 35:2 (2000), 215 ff; Neville Alexander, "Nasiebou en subnasionale identiteite in Suid-Afrika na 1994", LitNet 12.08.2010, at www.litnet.co.za/cgibin/giga.cgi?cmd=cause_dir_news_item\&cause_id=1270\&news_id=91141\&cat_id=163. 
In the South African context, such leaders were the products of the struggle between white Afrikaners and English speakers for dominance across racial boundaries. Blacks were treated as pawns in this struggle in a manner akin to the way Third World countries came to be used by the USA and the Soviet Union during the Cold War. Whereas the National Party government had, with limited success, sought allies among black traditional leaders and the rural population in the so-called black 'homelands', the white liberal establishment had chosen to target the growing urban population and, more specifically, the small emerging middle class among them. The leadership of the ANC came from among the latter group.

This is not to blame or criticise the ANC. In any social movement, the leadership tends to be drawn from among the middle class, and the white liberal establishment in South Africa had a vested interest in reaching out to this class among black South Africans at the time that they did. Struggle leaders can hardly be blamed for making use of the opportunities this offered to them to acquire skills and resources that could benefit the movements they were establishing. ${ }^{29}$ The important thing is not to assign blame, but to understand the dynamics inherent in our history and our present situation. With such an understanding, decision-makers within the ANC government of today might avoid the pitfalls awaiting them as the new elite, as long as the political will to do so is present.

The post-1994 political economy has, to a significant extent, moved away from the racial demarcations of the past. The elite of our country has become increasingly multiracial as public institutions and the private sector have begun to be transformed in racial terms. However, we should not fool ourselves into believing that a capitalist economy in a country such as ours, and at the present juncture in our history, can be all-inclusive, i.e. that it can function without boundaries.

At present, our economy is simply not large enough to provide the same opportunities for everyone. Inequality will be with us for some time. Whether the capitalist economy will, in time, be replaced by a post-capitalist alternative of some kind, or whether it will grow at a sufficient pace to remain stable and absorb increasing numbers of the presently marginalised over the long term, is an important debate in itself. But whatever the case may be, it is of the utmost importance that we prevent the socio-economic cleavages in our society from becoming irreversibly attached to other boundary markers that might come to take the place occupied by race during the 20th century, thereby acquiring more permanence than might be necessary.

As I have pointed out, the danger is very real that language may come to fulfil this function. It is well suited for this purpose since, while it allows for increasing numbers of black South Africans to enter the ranks of the privileged - thereby bestowing credibility on the system - it draws the line precisely where the neo-liberal market suggests it should be drawn. At present, about half of the population are excluded from meaningful, beneficial participation in the economy, and are still trapped in poverty. Similarly, about half of the population are not functionally proficient in English. Just as the vast majority of the poor in South Africa are black, the vast majority of non-English-proficient South Africans are also black. This includes the rural dwellers and women who subsist on the margins of our economy, and in general the very same people who do not have realistic access to English as a language of empowerment.

Thus the boundaries of privilege have come to correspond quite starkly with linguistic boundaries. This state of affairs is masked by the dramatic and visible deracialisation of our

29 See Johnson, ibid: "Perhaps it is best to say that this was a case of unintentional elitism with the best of intentions." 
society in the higher echelons, and the fact that many among the English-proficient elite have a language other than English as their mother tongue. (We have yet to learn to analyse our linguistic dynamics in terms of proficiency rather than home language, as is shown by the census, which enquires only after the 'home language' of respondents, and not their proficiency, or lack thereof, in other languages.) The danger, then, is that those who currently benefit from the system might come to form a new, quasi-ethnic (though multiracial) block, with a culture, networks and interests quite distinct from those of the majority. Functional proficiency in English, unattainable for the majority for the foreseeable future, may become a convenient means of drawing stark boundaries in order to protect the interests of this privileged block, in a manner uncannily similar to the way race functioned as such a boundary in the past.

In other words, the contingent, non-blameworthy historical fact that members of the emerging elite tend to be proficient in English, whereas the poor tend not to be, may inadvertently lead to a situation where English proficiency is no longer simply a concomitant of opportunity and privilege, but a condition for it. Our transition may come to be characterised by disillusioned future generations as a transition from racial to linguistic capitalism, transforming our society from a racist into a linguicist one.

We are at a juncture in our history where it is still possible, through strategic and visionary interventions by political and other leaders, to avert the kind of scenario that I am warning against. It is therefore of the utmost importance that the state should take immediate and drastic steps to prevent proficiency in English from becoming further established as a marker of opportunity and privilege.

It should no longer be taken for granted that whoever wishes to improve their lot, and that of their communities, by becoming educated, entering the job market, and striving for leadership positions, should first acquire English. Creative language policies can turn proficiency in our indigenous languages - a skill already possessed in abundance by the millions of poor people in our country - into cultural capital with which to access opportunities for advancement. Equitable use of the official languages by government and public institutions like the public broadcaster, mother-tongue-based multilingual education from the primary to the tertiary level, making proficiency in languages other than English a condition for employment in the civil service, awarding state contracts and tax benefits to companies with multilingual policies, and valorising the indigenous languages by using them for high-status functions, such as important addresses by political leaders, would prevent the serious remaining inequalities in our society from becoming cast in stone along the lines of a linguistic barrier.

South Africa cannot afford a new apartheid, a new 'pass system', where English takes the place of the old 'dom pas'. This society has a responsibility - and a historic opportunity - to show the world that a political transition can result in real benefits to all concerned, regardless of the colour of their skin, or the habit of their tongue. ${ }^{30}$

\section{Language, Black Power and Black Theology}

The North Gauteng High Court recently ruled that the national government has failed to regulate and monitor its use of official languages as required by article 6(4) of the

30 See also my ‘The Language Debate: Balkanisation or One Lingua Franca?’, Umrabulo 11 (June-July, 2001). 
Constitution of the Republic of South Africa. ${ }^{31}$ Why should such neglect on the part of the state - and the general failure of most institutions, both public and private, to give practical effect to the Bill of Rights' vision of 11 official languages enjoying 'parity of esteem' and 'equitable treatment' - be a matter of concern to black theologians? A short answer was provided by Noam Chomsky when he famously stated that 'questions of language are ... questions of power, ${ }^{32}$ Given the centrality of the issue of power in Black Theology through the decades, ${ }^{33}$ this perspective is of particular relevance in the present context.

The value of viewing 'questions of language' from a power perspective is that it helps to demystify the topic - to remove it from the context of cultural self-indulgence and nostalgia - thereby avoiding the dangers of Kulturchristianismus, Volkskerk and culture worship. Ethically speaking, what is at stake in language politics is not whether particular cultural elements can be conserved unchanged for future generations - that would be to make of language a fetish or even an idol - but rather whether the never-ending process of intercultural engagement can be managed in such a way that those affected by it can have more of a real say about which elements of their existing culture they are to retain, which elements they want to change or reject, and which cultural goods originating from other traditions and heritages they wish to take over and develop in new ways.

In debates between practitioners of African theology and Black Theology this point has been of central importance. When black theologians like Manas Buthelezi criticised African philosophy and theology ${ }^{34}$ (also sometimes sarcastically called: the 'ethnographic' approach) they were not suggesting that traditional African culture was worthless, but rather that black emancipation would mean freedom for black people to take from both African and Western cultures what they found useful and valuable in facing the challenges of their context.

In moving towards realising this dream, language has a central role to play. If those faced with the challenge of negotiating between traditional and modern cultural elements can use language as a bridge between the two worlds, e.g. by being able to access education, science, the media, politics etc. through the same languages used at home and in traditional African cultural settings, it would mean that elements of the one cultural tradition are carried over into the other, and vice versa, rather than the two standing starkly over against the other. This has been illustrated in the case of that part of the Afrikaans speaking community who has had the historical opportunity to access modern culture through their own 'kitchen language'. Not only has this made access to the domains in question easier for them, but it has enabled them to leave their own stamp on the 'foreign' cultural elements, and has even, paradoxically contributed to the ease with which they could acquire English and other languages.

31 The relevant section in the original judgment by judge R Du Plessis (case number 49807/09) reads: "Dit word verklaar dat die nasionale regering in versuim is om ingevolge artikel 6(4) van die Grondwet van die Republiek van Suid-Afrika 1996 deur wetgewende en ander maatreëls die nasionale regering se gebruik van amptelike tale te reël en te monitor."

32 Noam Chomsky, Language and Responsibility, Hassocks 1979, 191, quoted in Andy Wood, The 1549 Rebellions and the Making of Early Modern England, Cambridge University Press, 2007, 143.

33 See e.g. James H Cone's classic Black Power and Black Theology, Maryknoll 1999 ( $1^{\text {st }}$ edition Harper \& Row, 1969).

34 See e.g. Manas Buthelezi, 'African Theology and Black Theology: A Search for a Theological Method', in: H-J Becken (ed.), Relevant Theology for Africa, Durban, 1973, 25; 'Toward Indigenous Theology in South Africa', in: Sergio Torres \& Virginia Fabella (eds.), The Emergent Gospel: Theology from the Underside of History, Maryknoll, 1978, 56-75; 'An African Theology or a Black Theology?', in: Basil Moore (ed.) The Challenge of Black Theology in South Africa, Atlanta, 1974, 29-35. 
Notice that this kind of approach leaves room for a critical attitude towards one's own culture, and for the intercultural dynamic. Both the reification of culture and the separatist notion of cultural 'purity' are undermined by it, but without simply accepting or welcoming a wholesale takeover by the cultures of dominant elites, which is always to the material advantage of the latter.

The historian Lamin Sanneh ${ }^{35}$ makes the point that, whereas, for Muslims, only the Qur'an in Arabic is the true Qur'an, Christians have often regarded translations of the Bible as no less the Word of God than the Greek and Hebrew texts. In fact, the Bible contains a New Testament that is itself a translation, drawing for its part from a Greek translation of the Old Testament. This is possible because the very foundation of these documents is an event that may be described as the translation of God, through the Holy Spirit, into a human being who shared a certain culture and spoke a certain language - not the language of the empire, but the language of a peripheral community in the world of that time, the Jews. When, in the book of Acts (2:1-13), the Spirit of Christ comes over the apostles, they speak not some imperial 'language of God' - be it Greek or Latin - but rather: 'everyone hears in his own tongue'. Behind this lies not only a Christology of Christ the translation of God, but a pneumatology of the Spirit as translator.

Add to this the confession in John's gospel (1:1) that the Christ is the translation of no less than the eternal Word of God, the source of all truth, of which sparks are to be found in the tradition, way of life and worldview of every community on earth, and it becomes clear how Christ both condemns and redeems every culture. What must be rejected, therefore, is not only the Marcionite heresy that wants to separate the Christ from his people, the Jews, and their tradition, but also the heresy opposed by Paul, according to which Gentile believers first had to become Jews before they could be fully welcomes into the church. The Jewishness of Jesus is essential because it testifies to how God can speak, and show God's self, through the cultural resources of a particular community. However, sharing this message means showing how the same Word can express itself through the resources of any other cultural tradition.

It is on this basis that the church can never accept the misuse of cultural and linguistic power to bolster a system of domination, nor the idolatrous claim that a situation in which the culture and language of the empire lords it over others can be natural or without alternative. ${ }^{36}$ The church's prophetic resistance to such a situation will have to begin in the way it conducts its own affairs. Whether in theology, worship or service, the church can never be mono-cultural or mono-lingual for the simple reason that it is called to speak the language of God, the language called translation.

Behind this analysis of the politics of language lies the simple insight that the language used as medium of communication in a particular domain determines who can access that domain. In a country where the vast majority of citizens are speakers of one of the African languages - and where proficiency in English correlates strongly with race and class, ${ }^{37}$ the dominance of English as the sole or main public language inevitably leads to the exclusion of the black majority from meaningful participation in public life and material benefits linked to such participation. As Neville Alexander writes: "An English-only, or even an

35 See Lamin Sanneh, Translating the Message, New York, 1989.

36 On the historical and contemporary link between (especially the English) language and empire, see Robert Phillipson, 'The Linguistic Imperialism of Neoliberal Empire', Critical Inquiry in Language Studies 5:1 (2008), 1-43.

37 See note 23 above. 
English-mainly, policy necessarily condemns most people, and thus the country as a whole, to a permanent state of mediocrity, since people are unable to be spontaneous, creative and self-confident if they cannot use their first language.",38

If, as I have suggested, ${ }^{39}$ Black Theology is meant to 'be expressed in African terms' (which would include using not only English, but also African languages), "reconcile Christianity with the African worldview" (a worldview that is inextricably linked to concepts and forms of expression in the African languages), 'address African problems' (like the colonisation of the mind ${ }^{40}$ and linguistic exclusion from public life), 'be rooted in the African church' (which itself is called to work for and embody linguistic justice), 'reconcile Christian commitment with liberation praxis' (including the praxis of liberating black people from linguistic oppression), "be "situational" (responding to the present situation of language dominance), 'be liberating' (for those who are linguistically marginalised), 'be accountable to the church of the poor' (which, unlike most secular institutions, functions largely multilingually), 'remain in conversation with the Christian tradition' (a tradition that begins and progresses through translation), 'remain faithful to the revelation in Christ' (God's translation into a human nature), and "submit to the authority of Scripture and church tradition" (which testifies to the divine economy of translation) - if these sorts of criteria are indeed applicable - then it seems clear that Black Theology should take up the theme of linguistic power with vigour.

3 Neville Alexander, 'Where English can Serve but not Empower', Guardian (11/01/2001), http://www.guardian.co.uk/education/2001/jan/11/tefl.guardianweekly.

39 See $\$ 2$ above

40 See Ngũgĩ wa Thiong'o, Decolonising the Mind: The Politics of Language in African Literature, London, 1986. 